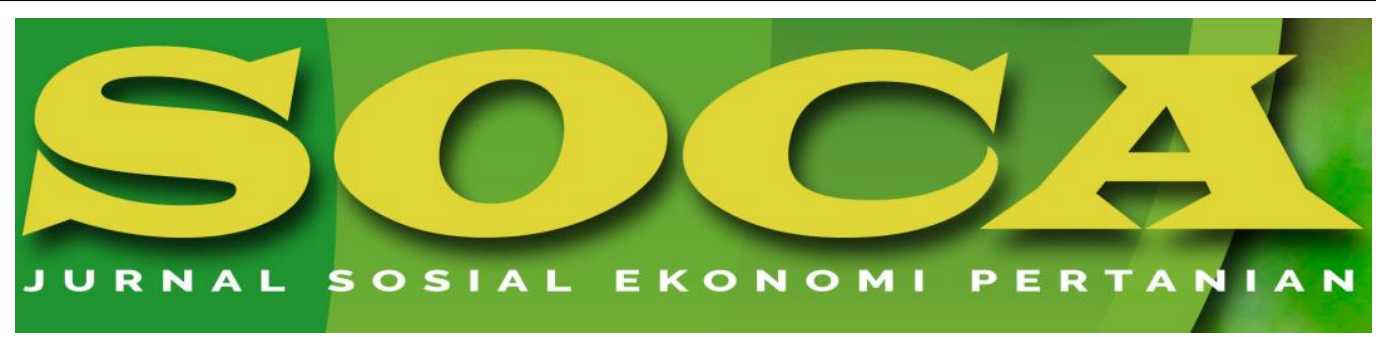

https://ojs.unud.ac.id/index.php/soca

\title{
The Analysis of Technical Efficiency of Inbred and Hybrid Lowland Rice Farming Business
}

\author{
Siti Sholikah ${ }^{1}$ and Kadarmanto ${ }^{2}$ \\ ${ }_{1}^{1}$ Directorate of Production Accounts, Statistics Indonesia \\ 2 Directorate of Food Crop, Horticulture and Plantation Statistics, Statistics Indonesia \\ Email: sitisholi@bps.go.id and kadarmanto@bps.go.id \\ Mobile: 087878620097 and 085697541702
}

Submitted: March 19th 2020 ; Revised: April 9'th 2020; Accepted: May 24th 2020

\begin{tabular}{ll}
\hline & Abstract \\
\cline { 2 - 3 } $\begin{array}{l}\text { Keywords: } \\
\text { Efficiency; }\end{array}$ & The background of this research was the unachieved rice \\
Frontier; & General of Crops in 2017. Hybrid lowland rice farmers were \\
Inbred; & assumed did not reach the full efficiency in the use of production \\
Hybrid; & and hybrid lowland rice farming business; analyzed the factors that \\
SFA & influence the level of business production, and analyzed the \\
& technical efficiency and the factors that influence the technical \\
& inefficiencies of the farming business. These aims can be answered \\
& by the Stochastic Frontier Analysis (SFA) method. The data used was \\
& the raw data of the Crops Cost Structure Survey 2017 in East Java \\
& Province. This province was chosen because it was the largest \\
& production contributor of rice field in Indonesia. Harvesting area, \\
& seeds and fertilizers gave a good effect to both for inbred and hybrid \\
& lowland rice production, and for hybrid rice production were also \\
& supported by labor. The technical efficiency of inbred lowland rice \\
& production was higher (81.17 percent) compared to hybrid lowland \\
rice production (70.49 percent). The factors that affected the technical \\
inefficiency of inbred lowland rice were gender, education, pest \\
control, tractors usage, counseling, and the number of labor, while \\
factors that affected to technical inefficiency of hybrid lowland rice, \\
education, pest control, and tractors usage.
\end{tabular}


How to Cite (APA 6th Style):

Sholikah, S., \& Kadarmanto. (2020). The Analysis of Technical Efficiency of Inbred and Hybrid Lowland Rice Farming Business. SOCA: Jurnal Sosial Ekonomi Pertanian, 14(3), 381-398. https://doi.org/https://doi.org/10.24843/SOCA.2020.v14.i03.p01

\section{INTRODUCTION}

The government has targeted food self-sufficiency as a manifestation of the seventh vision contained in the program of 2015-2019 Nawacita Kabinet Kerja. The food availability in sufficient quantities and good quality food has a wide impact on the economy and the quality of human resources (Ministry of Agriculture, 2018). Rice as the main foodstuff for Indonesian was the target of the government to achieve selfsufficiency. In relation to this matter, the Directorate General of Food Crops (2015) established a Catur Production Achievement Strategy where one of the main focuses was to increase rice productivity by using superior seeds, such as inbred and hybrids.

Based on research by Krishnamurti \& Biru (2019), the average seasonal productivity of hybrid lowland rice can reach 7 tons / ha or higher than the average seasonal productivity of inbred lowland rice which only reached 5.15 tons / ha. However, this potency has not been fully used by rice farmers. This was indicated by the hybrid lowland rice planting area which was only less than one percent of the total rice planting area in Indonesia. In addition, the results of the 2017 Rice Business Cost Structure survey showed that the majority of lowland rice households (86.39 percent) cultivated inbred lowland rice varieties, while only 13.61 percent of hybrid lowland rice was cultivated (Central Bureau of Statistics, 2017).

East Java Province is one of the provinces that have the potential in agricultural sector. This can be seen from the area of rice fields up to $1,176,650$ hectares or 24.62 percent of the total land area in East Java Province which has the potential to develop rice. According to the East Java Central Bureau of Statistics (2018), from 2013 to 2017, East Java Province had the largest contribution to lowland rice production, which was around 17 percent of the total national lowland rice production. In addition, the productivity of lowland rice in East Java Province was also above the average national productivity. The increased of rice production was mainly because of the increased productivity through various intensification programs. However, during the last two years (in 2016 and 2017) the rate of increase in the rice productivity has been slower so that the growth of rice production has also decrease. This condition was also in line with the rice harvested area which experienced a slowdown in growth in 2016 even in 2017 experienced a decrease in the number of harvested areas.

According to Irawan (2004), the decrease in rice productivity was caused by two factors they are (1) the decrease in the use of high yield rice varieties, and (2) the decrease of farming quality. In line with this theory, based on the Guidelines for the Implementation of Rice Activities, hybrid lowland rice was not able to achieve the productivity targets ( 80 quintals / ha) that have been set nationally, the realization of productivity was only 55.42 quintals / ha (Directorate General of Food Crops, 2016). Along with un-achievement targets, this has an impact on a very drastic reduction in rice production which reached 4.54 percent in 2017. Meanwhile, inbred 
lowland rice RTUP was able to achieve productivity targets (55.31 quintals / ha) with the realization of productivity which was 55.31 quintals / ha. However, the percentage of inbred lowland RTUP that included in the high productivity category was still below the hybrid lowland rice RTUP. Based on the description above, it was suspected that there has been inefficiency in the use of inbred and hybrid rice varieties in East Java so that the potential productivity that should be exploited and achieved by farmers being not optimal.

Several studies related to the efficiency of production factors have been done. Kusnadi et al. (2011) researched the efficiency of rice farming in several rice production centers in Indonesia using the SFA method with an average efficiency result of 91.86 percent. Tinaprilla (2012) used the Stochastic Metafrontier Production Function Approach method to determine the efficiency of rice production in central provinces with the result that each central province has been efficient with a technical efficiency index more than 80 percent. Rivanda et al. (2015) also stated that the lowland rice business in Tegalsari District was technically efficient. Although research on technical efficiency has been done a lot, but this research was different from previous studies because it examined the technical efficiency of the commodity inbred and hybrid rice that have not been done much by previous researchers.

The research on the technical efficiency of inbred and hybrid lowland rice farming was important to be done. This was because in order to create sustainable food self-sufficiency, increasing production through increasing technical efficiency in farming was an alternative solution. This research aimed to 1) discover the general picture of inbred and hybrid lowland rice farming 2) analyze the variables that affect the level of inbred and hybrid lowland rice production 3) analyze technical efficiency and 4) analyze the variables that affect the technical inefficiency of Inbred and hybrid lowland rice farming business in East Java Province in 2017.

\section{RESEARCH METHODS}

The data used in this research were raw data from the survey results of the Food Crop Costing Business Structure (SOUT) of East Java Province in 2017 obtained from the Central Bureau of Statistics (BPS). East Java was chosen as the location of the research because this province has the largest rice fields in Indonesia which was potential for the development of both inbred and hybrid rice fields. In addition, East Java has the largest contribution of lowland rice to national lowland rice production and the productivity of lowland rice was above the national average. Based on this potency, the Director General of Food Crops bold to target a high level of productivity towards inbred and hybrid rice varieties.

This research used descriptive analysis and inference analysis methods. To answer the first aim, descriptive analysis was used in the form of pictures, tables and brief descriptions, while to answer the second, third, and fourth aims, using inference analysis which used the Stochastic Frontier Analysis (SFA) method. Mathematically, the equation of the frontier stochastic production function can be written as follows:

Which:

$$
Q_{i}=\beta_{0} X_{1}^{\beta_{1}} X_{2}{ }^{\beta_{2}} X_{3}{ }^{\beta_{3}} X_{4}{ }^{\beta_{4}} e^{g}
$$

$Q_{i} \quad=$ The total production of past year $(\mathrm{kg})$,

$\beta_{0} \quad=$ intercept, 
$\beta_{j} \quad=$ production elasticity to the production factors of inbred and hybrid rice farming business the $-j(j=1,2,3,4)$,

$\mathrm{X}_{1} \quad=$ harvested area for the past year $\left(\mathrm{m}^{2}\right)$,

$\mathrm{X}_{2} \quad=$ the amount of seed used for the past year $(\mathrm{kg})$,

$\mathrm{X}_{3} \quad=$ the amount of fertilizer used for the past year $(\mathrm{kg})$,

$\mathrm{X}_{4} \quad=$ number of employees (male and female) for the past year (HOK),

e(g) $\quad=$ error, where $g=V_{i}-U_{i}$,

$\mathrm{V}_{\mathrm{i}} \quad=$ random model error,

$\mathrm{U}_{\mathrm{i}} \quad=$ the error which can be controlled by the business unit that represented technical inefficiency,

This technical efficiency of inbred and hybrid rice farming business was assumed using equation that formulated as follow:

$$
T E_{i}=\frac{q_{i}}{\exp \left(x \prime_{i} \beta_{i}+v_{i}\right)}=\frac{\exp \left(x \prime_{i} \beta_{i}+v_{i}-u_{i}\right)}{\exp \left(x^{\prime} \beta_{i}+v_{i}\right)}=\exp \left(-U_{i}\right)
$$

Therefore, the estimated technical efficiency from an industry was the average efficiency estimation from a business unit which used as a sample, as follow:

$$
\overline{T E}=\frac{1}{l} \sum_{i=1}^{l} \widehat{T E}_{i}
$$

Then, the RTU characteristic factors which assumed to affect the technical inefficiency were gender, education, pest control, tractor usage, counseling and the number of household members. Mathematically, the equation of insufficiency factors can be written as follow:

$$
\text { TIE }_{i}=\delta_{0}+\delta_{1} J K_{i}+\delta_{2} \text { Pend }_{i}+\delta_{3} \text { Hama }_{i}+\delta_{4} \text { Traktor }_{i}+\delta_{5} \text { Suluh }_{i}+\delta_{6} A R T_{i}+C_{i}
$$

Where:

$\mathrm{TIE}_{\mathrm{i}}$

$\delta_{0}$

$\delta_{1}, \delta_{2}, \delta_{3}, \delta_{4}, \delta_{5}, \delta_{6}$

JK

Pend

Hama

Traktor

Suluh

ART

$\mathrm{C}_{i}$
$=1-\mathrm{TE}_{\mathrm{i}}=$ was the household technical inefficiency value the-i,

= intercept,

$=$ parameters whose values were estimated through the estimator model,

$=$ the main farmers gender $($ men $=1$ or women $=0)$,

$=$ degree/the higher education certification that owned by the main farmer (minimum junior high school graduate $=1$ or not junior high school graduate $=0$ )

$=$ pest control which done by RTU (yes $=1$ or no=0)

$=$ the use of equipment in land cultivation (tractor=1 or animal and human=0)

$=$ counseling obtained by RTU (yes $=1$ or no=0)

$=$ number of household members (less than equal with $4=1$ or more than $4=0$ )

$=$ household error term the-i 


\section{RESULT AND DISCUSSION}

\section{The General Picture of Inbred and Hybrid Rice Farming Business in East Java in 2017}

Below was the picture of inbred and hybrid lowland rice farming business in East Java in 2017:

Table 1 . The average production and inbred and hybrid lowland rice farming business production factors in East Java

\begin{tabular}{ccc}
\hline \multirow{2}{*}{ Variables } & \multicolumn{2}{c}{ Average } \\
\cline { 2 - 3 } & Inbred & Hybrid \\
\hline Production $(\mathrm{kg})$ & $(2)$ & $(3)$ \\
Harvesting Area $\left(\mathrm{m}^{2}\right)$ & $3.227,55$ & $1.784,61$ \\
Seeds $(\mathrm{kg})$ & $5.863,90$ & $3.240,24$ \\
Fertilizer $(\mathrm{kg})$ & 53,86 & 51,44 \\
Labor $(\mathrm{HOK})$ & 827,35 & 899,40 \\
\hline
\end{tabular}

Source: raw data SOUT 2017 (processed)

Based on Table 1, it can be shown that in general the average production of inbred lowland rice was $3,227.55 \mathrm{~kg}$, while the average production of hybrid lowland rice was $1,784.61 \mathrm{~kg}$ in one year. Meanwhile, the average of RTU harvest area for inbred rice in East Java reached $5,863.90 \mathrm{~m} 2$, while the average harvest area for RTU hybrid rice was lower, at 3,240.24 $\mathrm{m} 2$. The regulation of the Minister of Agriculture (2007) has arranged the use of seeds in farming business; they were inbred seeds at $25 \mathrm{~kg} /$ hectare, while hybrid seeds at $15 \mathrm{~kg} /$ hectare. The average use of seeds by inbred lowland rice RTUs was $53.86 \mathrm{~kg} /$ hectare, while hybrid RTUs used seeds with an average of $51.44 \mathrm{~kg} /$ hectare. Thus, it can be said that both the inbred and hybrid rice RTU used excessively seed in farming business. Picture 1 showed that inbred lowland rice RTU which used Ciherang variety seed in production was 60.22 percent. Meanwhile, Intani 1 variety seeds were used by most $(28.51$ percent) hybrid lowland rice RTU.

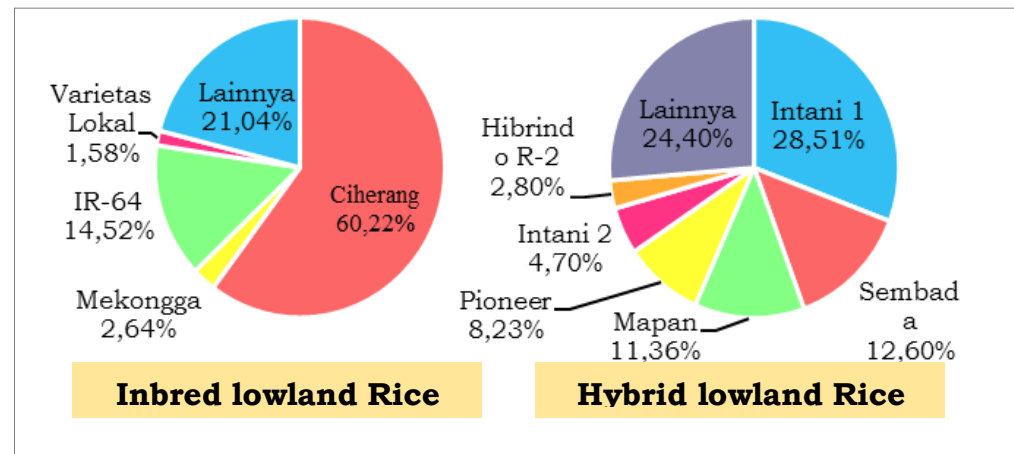

Picture 1. Percentage of inbred and hybrid lowland rice RTU based on main seed variety that used

Source: raw data SOUT 2017 (processed)

Picture 1 information:

Varietas Lokal = Local Varieties

Lainnya = others 
IR-64, Mekongga, Ciherang, Hybrind, Intani 2, Pioneer, Mapan, Sembada and Intani 1 are the name of seed varieties.

The average usage of fertilizer in inbred lowland rice RTU was $827.35 \mathrm{~kg} /$ hectare while in hybrid lowland rice RTU was $899.40 \mathrm{~kg} /$ hectare. The regulation of the Minister of Agriculture (2007b) has provided fertilizer recommendations namely urea fertilizer of 250-300 kg / hectare, TSP / SP36 of 50-100 kg / hectare, ZA of 100 $\mathrm{kg} / \mathrm{hectare}, \mathrm{KCl}$ of $50-100 \mathrm{~kg} /$ hectare and NPK fertilizer of $150-250 \mathrm{~kg} /$ hectare. Picture 2 showed that the usage of fertilizer in inbred lowland rice RTU which appropriate to the recommendation was only Urea fertilizer, whereas TSP / SP36 fertilizer used tend to be excessive, and $\mathrm{ZA}, \mathrm{KCl}$, and NPK fertilizers were used in too small amounts. Meanwhile the usage of fertilizers in hybrid rice RTU which appropriate with the recommendations were Urea, TSP / SP36, and NPK while ZA and $\mathrm{KCl}$ fertilizers were given to the crops in too small amounts.

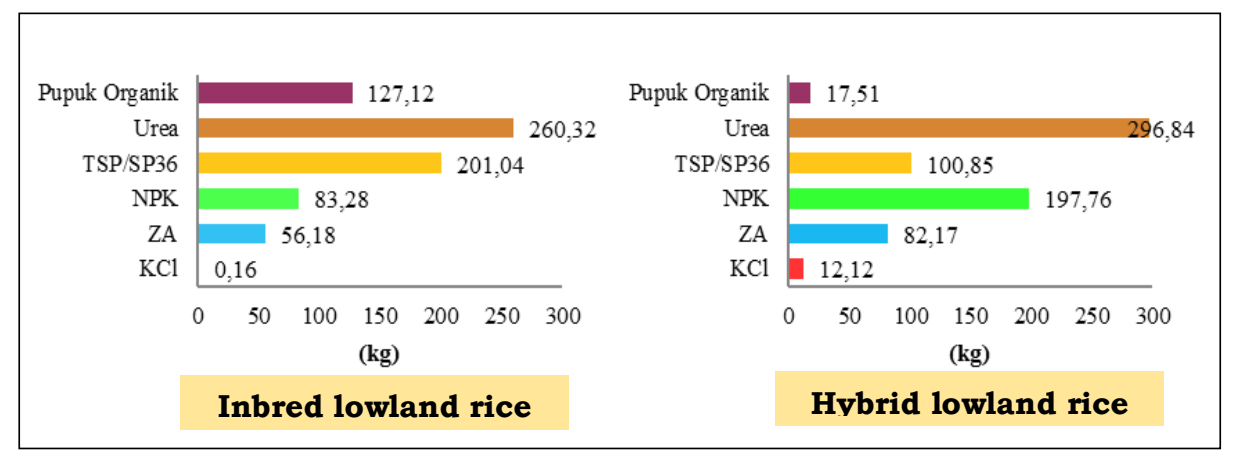

Picture 2. The average used of inbred lowland rice RTU fertilizer based on the fertilizer varieties that were used Source: raw data SOUT 2017 (processed)

Picture 2 information:

Pupuk Organik = Organic Fertilizer

Urea, TSP/SP36, NPK, ZA, KCL are the name of fertilizer varieties.

The average used of labor in inbred lowland rice RTU was higher (37 HOK) compared to hybrid lowland rice RTU (30 HOK). Based on Picture 3, it can be shown that the average men labor that employed by inbred lowland rice RTU was 18 HOK and women labor was 20 HOK. Meanwhile, the average men labor that employed by hybrid lowland rice RTU was $15 \mathrm{HOK}$ and women labor was 16 HOK.

The following picture was a general description of the characteristics of inbred and hybrid lowland rice RTU in East Java in 2017:

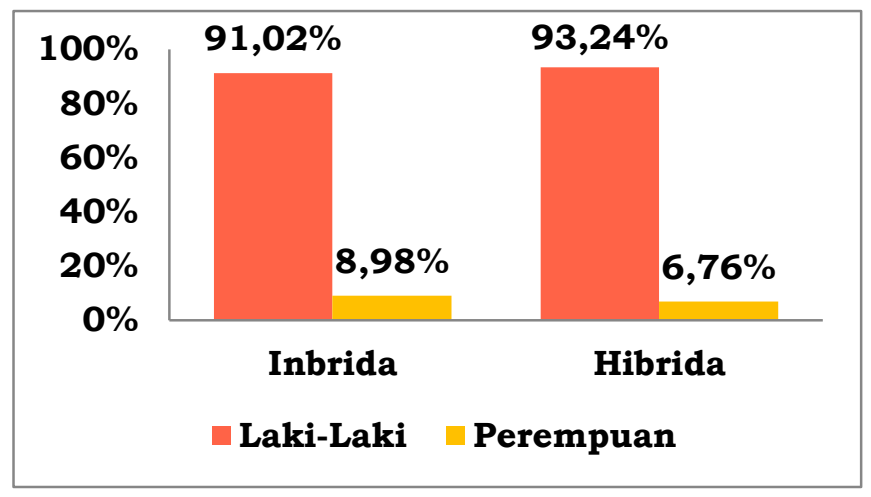

Picture 3. Percentage of inbred and hybrid lowland rice RTU based on gender Source: raw data SOUT 2017 (processed) 
Picture 3 information:

$\begin{array}{ll}\text { Inbrida } & =\text { Inbred } \\ \text { Hibrida } & =\text { Hybrid } \\ \text { Laki-laki } & =\text { Men } \\ \text { Perempuan } & =\text { women }\end{array}$

In general, the majority of the main farmers for both inbred and hybrid lowland rice were men. Figure 5 showed that the percentage of men farmers on inbred rice was 91.02 percent, while women farmers were 8.98 percent. Meanwhile, the percentage of men farmers in hybrid rice was dominated reaching 93.24 percent, while the remaining 6.76 percent were women farmers.

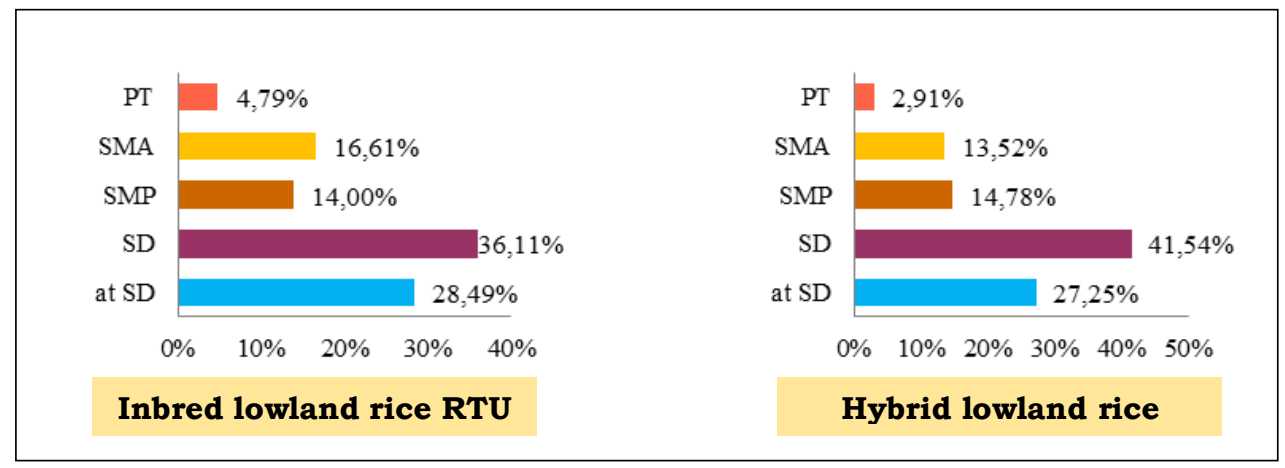

Picture 4. Percentage of inbred and hybrid rice RTU based on the main farmers education Sumber: raw data SOUT 2017 (processed)

Picture 4 information:

$\begin{array}{ll}P T & =\text { University } \\ \text { SMA } & =\text { High School } \\ \text { SMP } & =\text { Junior High School } \\ \text { SD } & =\text { Elementary School }\end{array}$

Then, the highest education completed by the main farmers of inbred and hybrid lowland rice was relatively low (Junior high school downward or does not meet the 9-year compulsory education). The percentage of main farmers who did not meet the 9-year compulsory education for both types of rice was each reached more than 50 percent.

Next, most of the inbred lowland rice RTU (93.82 percent) and hybrid lowland rice (86.77 percent) that experienced pest / OPT attacks had carried out pest control efforts. Furthermore, Picture 5 explained that the percentage of inbred lowland rice RTU using tractors as the main land cultivation tool reached 91.04 percent, while those using animals and human employee were 8.96 percent. Meanwhile, 84.08 percent of hybrid rice RTU used tractors in land cultivation activities, while those using animals and human employee amounted to 15.92 of the total hybrid rice RTU. 


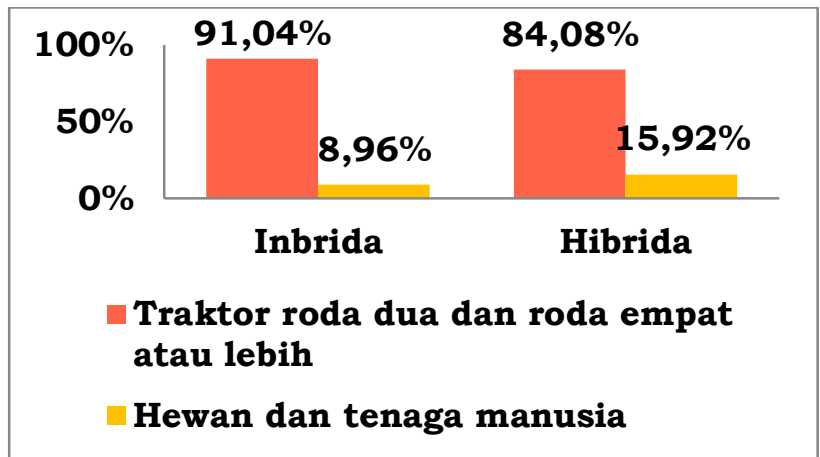

Picture 5. Percentage of inbred and hybrid lowland rice RTU based on main land cultivation tools

Source: raw data SOUT 2017 (processed)

Picture 5 information:

Inbrida = Inbred

Hibrida $\quad=$ Hybrid

Traktor roda dua dan roda empat atau lebih = two wheels tractor and four wheels or more Hewan dan tenaga manusia = Animals and human employee

In general, the majority of rice RTU did not participate in counseling / guidance regarding the management of the rice crop business. The percentage of inbred rice RTU participating in counseling was 40.23 percent while 59.77 percent did not participate in counseling. The same thing happened in the hybrid rice crop business where only 21.45 percent participated in counseling in the region, while the remaining 78.55 percent did not attend the counseling. According to Junaedi (2016), the condition of the large number of farmers which not participating in counseling could be due to the absence of the counseling activities from a counseling institution or due to the absence of farmers when the counseling activities were held.

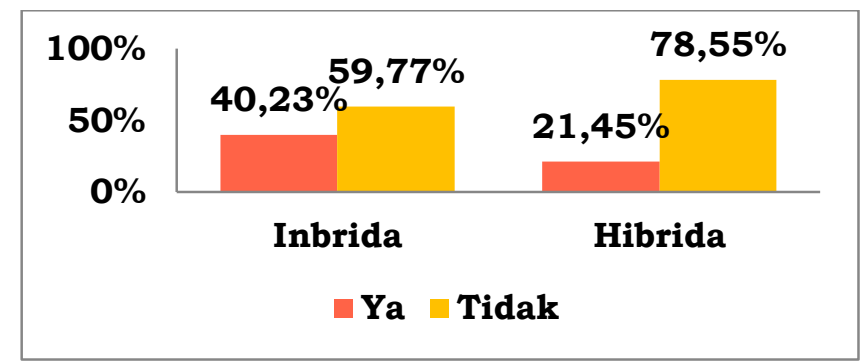

Picture 6. Percentage of inbred and hybrid lowland rice RTU based on the counseling participation

Source: raw data SOUT 2017 (processed)

Picture 6 information:

$\begin{array}{ll}\text { Inbrida } & =\text { Inbred } \\ \text { Hibrida } & =\text { Hybrid } \\ \text { Ya } & =\text { Yes } \\ \text { Tidak } & =\text { No }\end{array}$

The average number of household members in inbred and hybrid lowland rice RTU was four people. Picture 7 showed that most (71.11 percent) inbred rice RTU had a maximum number of ART 4 people, while those who had more than 4 ART members were 28.89 percent. Likewise in hybrid rice RTU, households that have a maximum of 4 people on ART were 73.88 percent, while the remaining 26.12 percent have more than 4 people on ART. Thus, it can be said that the majority of inbred and 
hybrid rice RTU were ideal families in appropriate to the government expectations in family planning.

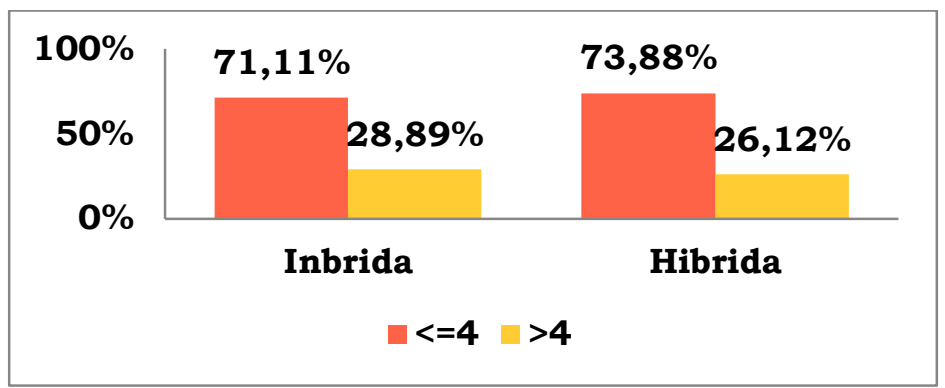

Picture 7. Percentage of inbred and hybrid lowland rice RTU based on the number of household family members Source: raw data SOUT 2017 (processed)

Picture 7 information:

Inbrida $\quad=$ Inbred

Hibrida = Hybrid

Based on Picture 8, it can be explained that the total cost per planting season for one hectare of inbred lowland rice harvest land was $\mathrm{Rp} 11.7$ million while hybrid lowland rice was Rp 11.25 million. The largest production cost for both types of lowland rice was the employee fee and agricultural services, which was Rp.5.59 million in inbred lowland rice and Rp 5.23 million in hybrid lowland rice. In addition, the second largest production cost was land rent, which was Rp. 3.78 million in inbred lowland rice and Rp. 3.11 million in hybrid lowland rice. Then, fertilizer expense on inbred lowland rice was Rp 1.68 million while in hybrid lowland rice was Rp 1.77 million. Furthermore, seeds expense amounted to 0.66 million inbred lowland rice, while in hybrid lowland rice 1.19 million. Meanwhile, the value of production per hectare per planting season for hybrid lowland rice was greater (Rp. 21.64 million) compared to the value of inbred rice production (Rp. 20.59 million).

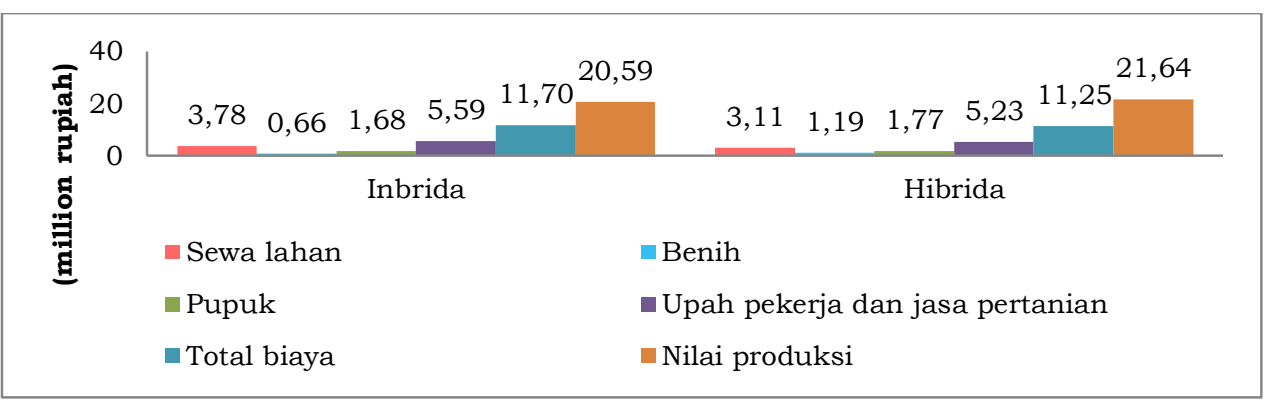

Picture 8. Cost average and production value of inbred and hybrid lowland rice crop business per planting season per hectare Source: raw data SOUT 2017 (processed)

Picture 8 information:

$\begin{array}{lll}\text { Inbrida } & =\text { Inbred } \\ \text { Hibrida } & =\text { Hybrid } \\ \text { Sewa lahan } & =\text { land rent } \\ \text { Pupuk } & =\text { fertilizer } \\ \text { Total biaya } & =\text { total cost } \\ \text { Benih } & =\text { seed }\end{array}$

Upah pekerja dan jasa pertanian $=$ Labor fee and agricultural services

Nilai produksi $=$ production value 


\section{The Variables that Influence Inbred and Hybrid Lowland Rice Production in East Java in 2017}

Before conducting an analysis related to technical efficiency, it was necessary to examine the effects of inefficiency. The first examination was examined the distribution of inefficiency components and second the examination of the inefficiency effects existence.

Table 2. Examination result of components distribution inefficiency function of inbred and hybrid lowland rice frontier production

\begin{tabular}{|c|c|c|c|c|c|}
\hline $\begin{array}{l}\text { Lowland } \\
\text { Rice } \\
\text { Varieties }\end{array}$ & Hypothesis & $\begin{array}{c}\text { Log } \\
\text { Likelihood }\end{array}$ & $\begin{array}{c}\text { LR } \\
\text { Statistic }\end{array}$ & Critical Value & Conclusion \\
\hline Inbred & $\begin{array}{c}H_{0}: \mu=0 \text { (half- } \\
\text { normal) } \\
H_{1}: \mu \neq 0 \text { (truncated- } \\
\text { normal) }\end{array}$ & $\begin{array}{l}-633,9676 \\
-425,0337\end{array}$ & 417,8677 & $\chi_{(0,05 ; 1)}^{2}=3,841$ & Decline $H_{0}$ \\
\hline Hybrid & $\begin{array}{l}\quad H_{0}: \mu=0 \text { (half- } \\
\quad \text { normal) } \\
H_{1}: \mu \neq 0 \text { (truncated- } \\
\text { normal) }\end{array}$ & $\begin{array}{r}-1287,1150 \\
- \\
-1279,348\end{array}$ & 15,5340 & $\chi_{(0,05 ; 1)}^{2}=3,841$ & Decline $H_{0}$ \\
\hline
\end{tabular}

Source: raw data SOUT 2017 (processed)

The value of the Likelihood Ratio (LR) of inbred lowland rice commodity was 417.8677 and hybrid lowland rice was 15.5340 which was greater than the value of the Chi-Square table with one free degree and alpha 0.05 of 3.841 so that it caused a decline in $H_{0}$, which mean a 95 percent confidence level, the inefficiency component assumed in the inbred lowland rice production and hybrid lowland rice production functions both follow the normal truncated distribution. The following were the examination results of the exsistence of the technical inefficiency effects in inbred and hybrid lowland rice frontier production functions:

Table 3. Examination results of the exsistence of the technical inefficiency effects in inbred and hybrid lowland rice frontier production functions

\begin{tabular}{|c|c|c|c|c|c|}
\hline $\begin{array}{c}\text { Lowland } \\
\text { Rice } \\
\text { Varities }\end{array}$ & Hypothesis & $\begin{array}{c}\text { Log } \\
\text { Likelihood }\end{array}$ & $\begin{array}{c}\text { LR } \\
\text { Statistic }\end{array}$ & $\begin{array}{l}\text { Critical } \\
\text { Value }\end{array}$ & Conclusion \\
\hline Inbred & $\begin{array}{c}H_{0}: \gamma=0 \text { (no } \\
\text { inefficiency effect) } \\
H_{1}: \gamma>0 \\
\text { (inefficiency effect) }\end{array}$ & $\begin{array}{c}-1.275,1073 \\
-270,4143\end{array}$ & $2.009,3860$ & $\begin{array}{c}\text { Mixed } \\
\text { Chi Square } \\
(0,05 ; 8)=14 \\
853\end{array}$ & Decline HO \\
\hline Hybrid & $\begin{array}{c}H_{0}: \gamma=0 \text { (no } \\
\text { inefficiency effect) } \\
H_{1}: \gamma>0 \\
\text { (inefficiency effect) }\end{array}$ & $\begin{array}{l}-1.521,8112 \\
-1.208,1000\end{array}$ & 627,4224 & $\begin{array}{c}\text { Mixed } \\
\text { Chi Square } \\
(0,05 ; 8)=14 \\
853\end{array}$ & Decline HO \\
\hline
\end{tabular}

Source: raw data SOUT 2017 (processed)

Table 3 showed the examination of the existence of technical inefficiency effects to discover whether the inefficiency component that has a truncated normal 
distribution was really in the production function or not. The examination result stated the decline of $\mathrm{H}_{0}$ at a significance level of 5 percent so that it can be said that with a confidence level of 95 percent there was an inefficiency effect on the production process of farming for both inbred and hybrid lowland rice in East Java.

Following were the estimated results of the frontier stochastic production function using the MLE approach:

Table 4. The estimated results of the Cobb-Douglas production function parameter MLE method

\begin{tabular}{cccccc}
\hline \multirow{2}{*}{ Variables } & \multirow{2}{*}{ Parameter } & \multicolumn{2}{c}{ Inbred } & \multicolumn{2}{c}{ Hybrid } \\
\cline { 2 - 6 } & & Coefficient & t-value & Coefficient & t-value \\
\hline Constant & $\beta_{0}$ & $-0,3502^{*}$ & $-8,8979$ & $0,1815^{*}$ & 2,4297 \\
ln Area (harvest area) & $\beta_{1}$ & $0,9543^{*}$ & 131,1227 & $0,8366^{*}$ & 60,3266 \\
ln Seed (seed amount) & $\beta_{2}$ & $-0,0487^{*}$ & $-7,2758$ & $0,0324^{*}$ & 4,0568 \\
ln Fertilizer (fertilizer & $\beta_{3}$ & $0,0811^{*}$ & 15,9064 & $0,0993^{*}$ & 11,6210 \\
amount) & $\beta_{4}$ & 0,0043 & 1,2148 & $0,0514^{*}$ & 7,4038 \\
ln TK (labor) & $\sigma^{2}$ & $2,1916^{*}$ & 9,6351 & $0,3968^{*}$ & 7,9667 \\
Variant & $\gamma$ & $0,9905^{*}$ & 944,4447 & $0,9423^{*}$ & 132,8882 \\
Variant ratio & $\gamma$ & & &
\end{tabular}

Information: * significance level of $5 \%$

Source: raw data SOUT 2017 (processed)

Table 4 showed that the parameter $\sigma^{2}$ was statistically significant at the level of 5 percent and was not 0 value (inbred lowland rice $\sigma^{2}=2.1916$ while hybrid lowland rice $\sigma^{2}=03968$ ), which means that inbred and hybrid rice farming have not been fully efficient. Then, the parameter $\gamma$ was also significant with a value of 0.9905 in inbred lowland rice and 0.9423 in hybrid lowland rice which showed that 99.05 percent of the error resulted came from the inefficient effects of inbred lowland rice farming and 94.23 percent of the error resulted from the inefficiency effects of hybrid rice farming. This showed that the role of the inefficiency effect was greater than the error random component (random error).

Based on the parameter estimation results, obtained the equation of the frontier Cobb-Douglas production function of inbred lowland rice as follows: In Prod_Inbred $_{\iota}=-0,3502^{*}+0,9543^{*} \ln$ Area $_{i}-0,0487^{*} \ln$ Seed $_{i}+0,0811^{*} \ln$ Fertilizer $_{i}+$ $0,0043^{*} \ln$ Labor $_{i}$

Whereas, the equation of the frontier Cobb-Douglas production function of hybrid lowland rice as follows:

$\ln$ Prod_hybrid $_{\iota}=0,1815^{*}+0,8366^{*} \ln$ Area $_{i}+0,0324^{*} \ln$ Seed $_{i}+0,0993^{*} \ln$ Fertilizer $_{i}+$ $0,0514^{*} \ln$ Labor $_{i}$

\section{The Variables that Influence Inbred Lowland Rice Production}

The harvested area variable had a coefficient of 0.9543 , means that each additional one percent of harvested area (assuming other inputs were constant) can increase 0.9543 percent of production. Inbred lowland rice production was the most responsive to harvested area because it has the greatest coefficient. This was a proper condition because in general the wider planting area will increase the amount of inbred lowland rice production. 
Then, the seed variable had a negative and significant effect on inbred lowland rice production. This means that every one percent increasing in the use of seeds decreased inbred lowland rice production by 0.0487 percent, assuming other inputs were constant. This was not in accordance with the initial hypothesis that the use of seeds can increase production. According to the Ministry of Agriculture in Kompas (2017), until mid-August 2017 around 67 thousand hectares of rice field areas were exposed to pests, namely brown plant hopper pests. East Java Province was one of the areas affected by the pest attack due to the majority of inbred lowland rice RTU using Ciherang variety that were susceptive to pest attacks. As a result of the pest disruption, inbred lowland rice RTU experienced a decreased production.

Furthermore, the use of fertilizer by inbred lowland RTU in East Java had a positive and significant effect on production with a coefficient of 0.0811 . This means that each additional one percent used of fertilizer will increase inbred lowland rice production by 0.0811 percent, assuming other inputs were constant. However, increasing the amount of fertilizer has to be based on the recommendations so it did not damage the soil organic element.

The labor variable was not significant to inbred lowland rice production which means it was not in accordance with the initial hypothesis. This is in line with the research of Kasturi (2012) which stated that the number of workers was not merely a determining factor for an increase in rice production due to any amount of labor employed but if the capacity was inadequate it will reduce production results.

\section{The Variables that Influence Hybrid Lowland Rice Production}

The harvest area variable was significant and has a positive effect on hybrid lowland rice production and has a coefficient of 0.8366 . This number showed that each additional one percent of harvested area (assuming other inputs were constant) can increase 0.8366 percent of hybrid lowland rice production. Hybrid rice production was more responsive to land compared to the other inputs.

Then, the use of seeds had a positive and significant effect on hybrid lowland rice production and had a coefficient of 0.0324 . This mean that each one percent increasing in seed used will increase hybrid lowland rice production by 0.0324 percent assuming other inputs were constant. In general, this showed the importance of using superior seeds to increase hybrid lowland rice production.

Furthermore, the use of fertilizer by hybrid lowland rice RTU in East Java had a positive and significant effect on production with a coefficient of 0.0993 . This mean that each additional one percent used of fertilizer will increase the production of hybrid lowland rice by 0.0993 percent, assuming other inputs were constant. However, increasing the amount of fertilizer has to be based on the recommendations in order to increase production and not to damage the soil organic element.

The labor variable had a positive effect on hybrid lowland rice production with a coefficient of 0.0514 . That mean, each additional one percent use of HOK will increase hybrid lowland rice production by 0.0514 percent, assuming other inputs were constant. 


\section{The Technical Efficiency Analysis of Inbred and Hybrid Lowland Rice}

The following was a distribution of the efficiency level that can be achieved by inbred and hybrid lowland rice RTU in East Java:

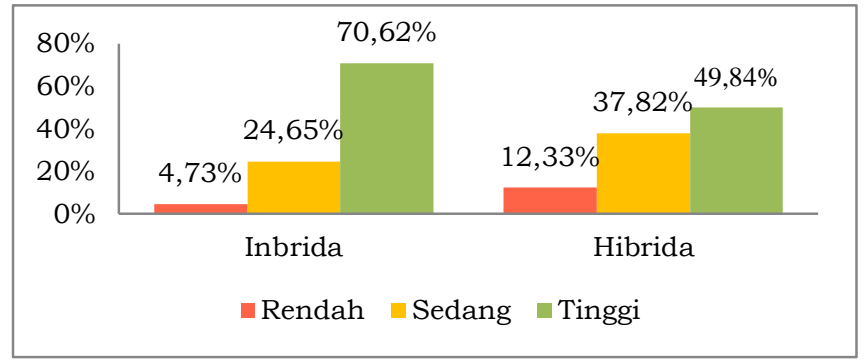

Picture 9. Distribution of technical efficiency level of inbred and hybrid lowland rice farming business

Source: raw data SOUT 2017 (processed)

Picture 9 information:

Inbrida $=$ Inbred

Hibrida = Hybrid

Rendah = Low

Sedang = Medium

Tinggi $=$ High

Based on Picture 9, it can be seen that the majority (70.62 percent) of inbred lowland rice RTU was included in the high efficiency category. Meanwhile, hybrid lowland rice RTU which in the high efficiency category was 49.84 percent or lower than inbred lowland rice RTU.

On average, inbred lowland rice RTU in East Java in 2017 had a technical efficiency of 0.8117 . This value was included in the high efficiency (more than 0.8) which means that this RTU has been able to achieve production realization of 81.17 percent to the maximum production limit but there was still a chance of about 18.83 percent to increase the ability of inbred lowland rice RUB through the output produced.

Meanwhile, the average level of technical efficiency produced by hybrid lowland rice RTU was 0.7049 or included in the category of medium efficiency. This means that, in general hybrid lowland rice RTU can only achieve production realization of 70.49 percent to the maximum production limit that should be achieved so that there was still an opportunity of around 29.41 percent to improve the performance of hybrid lowland rice RTU through the output produced.

Therefore, further analysis needs to be done on the factors that influence the inefficiency of inbred and hybrid lowland rice production in East Java in 2017. The following was the parameter estimation results of the RTU characteristic variables used in this research:

Table 5. The estimated results of the technical inefficiency function parameter MLE method

\begin{tabular}{lccccc}
\hline \multirow{2}{*}{ Variables } & \multirow{2}{*}{ Parameter } & \multicolumn{2}{c}{ Inbrid Lowland Rice } & \multicolumn{2}{c}{ Hybrid Lowland Rice } \\
\cline { 2 - 6 } & & Coefficient & t-value & Coefficient & t-value \\
\hline Constant & $\delta 0$ & $-6,0552^{*}$ & $-7,6246$ & $0,3860^{*}$ & 3,2409 \\
JK (gender) & $\delta 1$ & $-0,7336^{*}$ & $-11,4971$ & $-0,0136$ & $-0,1872$
\end{tabular}




\begin{tabular}{lccccc} 
Pend (education) & $\delta 2$ & $-0,3968^{*}$ & $-8,8093$ & $-0,2816^{*}$ & $-4,8808$ \\
$\begin{array}{l}\text { Pest (pest control) } \\
\text { Tractor (tractor usage) }\end{array}$ & $\delta 3$ & $1,6421^{*}$ & 10,1372 & $-0,4659^{*}$ & $-6,9693$ \\
$\begin{array}{l}\text { Counseling (counseling } \\
\text { participation) }\end{array}$ & $\delta 5$ & $-4,0706^{*}$ & $-11,7266$ & $-0,2173^{*}$ & $-4,6265$ \\
$\begin{array}{l}\text { ART (number of } \\
\text { household members) }\end{array}$ & $\delta 6$ & $0,2770^{*}$ & 7,1503 & $-0,0542$ & $-1,3911$ \\
\hline
\end{tabular}

Information: * significance level of $5 \%$

Source: raw data SOUT 2017 (processed)

Table 5 showed that of the six RTU characteristic variables used, all variables were statistically significant to technical inefficiencies with the level of 5 percent in inbred lowland rice, whereas in hybrid lowland rice there were only 3 significant variables, they were education, pest control and tractor usage. The following was the inefficient equation for inbred lowland rice:

TIE_Inbred $_{\iota}=-6,0552^{*}-0,7336^{*}$ JK $_{i}-0,3968^{*}$ Pend $_{i}+1,6421^{*}$ Pest $_{i}-4,0706^{*}$ Tractor $_{i}-$ $0,8559^{*}$ Counseling $_{i}+0,2770^{*} A R T_{i}$

As for, the inefficiency adequation of hybrid lowland rice as follows:

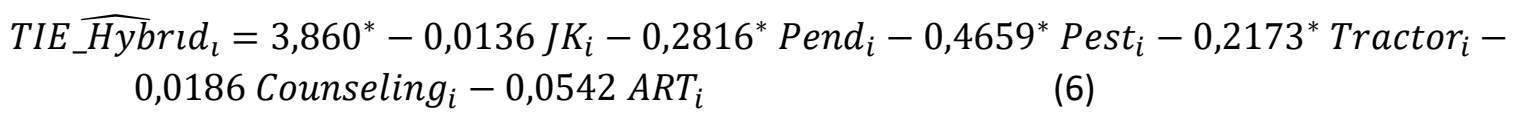

\section{The variables that Influence Technical Inefficiency of Inbred and Hybrid Lowland Rice}

\section{The variables that influence the technical inefficiency of inbred lowland rice}

The dummy variable of main farmers' gender as the farming business administrator negatively influenced the inefficiency of inbred lowland rice production. This means that men farmers can reduce inefficiency compared to women farmers in inbred lowland rice farming. This was because women have obligations in taking care of the household and caring for children while farming activities required intensive maintenance from planting to harvesting so that the use of women labor was more inefficient.

The dummy coefficient of the education variable has a negative sign, means that RTU with main farmers graduated from Junior High School and above can reduce the technical inefficiencies in inbred lowland rice production compared to RTU whose main farmer education has not yet completed Junior High School or below. This was in accordance with the results of Junaedi's (2016) research which stated that higher education will improve the quality of farm management because there was an increase in insight, the ability to access information and curiosity. Thus, farmers became more mature in making farm business decisions so that they can boost production and improve farm business efficiency.

The pest control dummy variable significantly influenced the inefficiency of inbred lowland rice farming with a positive coefficient. This means that RTU that perform pest control will be able to increase inefficiencies in performing inbred lowland rice farming activities. This could be happened because according to the 
Ministry of Agriculture in Kompas (2017) until mid-August 2017 there have been brown plant hopper pests that have occurred in several regions including East Java. Facing this condition the RTU no longer respect the rules of pest control, but took a quick way to over-use pesticides which were actually inefficient.

Meanwhile, the dummy variable of tractor usage had a negative influence on technical inefficiency which means that land cultivation with tractors can reduce inefficiency. The conditions of inbred lowland rice farming in East Java were relatively outspread so that the use of a tractor can save time and labor.

The counseling dummy variable had an influence on technical inefficiency with a negative sign which means that the participation in counseling activities can reduce the inefficiency of inbred lowland rice farming. This was in accordance with the initial hypothesis that farmers who participate in counseling will get knowledge about the use of inputs which appropriate to the recommendations, changes in cultivation techniques, the new and superior inputs usage, the optimal number of inputs, and technological improvements.

The dummy variable of number of ART/household members influenced the technical inefficiency with a positive sign which means that RTU with the number of ART less or equal to four can increase the inefficiency of inbred lowland rice farming. This contradicts to the initial hypothesis that farmers with a large number of household members will increase the high expense for consumption in the household so that the purchase of production inputs will be limited and caused the use of production inputs to be incompatible with the recommended use. However, this was in accordance with the results of research by Nwaru et al. (2011) which stated that the higher number of ART actually reduces the inefficiency of farming. This was because rural households tended to use family workers in farming rather than having to employ workers outside the family so that farmers can reduce the expense of labor costs in managing their farming business.

\section{The variables that influence the technical inefficiency of hybrid lowland rice}

The education level of farmers had a negative signed coefficient, means that RTU with main farmers graduated from Junior High School or equivalent will reduce inefficiency. The higher level of formal education received by farmers will improve the quality of farming management business because there was an increase in insight, the ability to access information and curiosity. Thus, farmers became more mature in making farming business decisions so that they can boost the production and improve farming business efficiency.

The pest control dummy variable significantly influenced the inefficiency of inbred lowland rice farming with a negative coefficient. This means that RTU which perform pest control will be able to reduce inefficiencies in performing hybrid lowland rice farming activities. This was in line with the results of research by Suharyanto et al. (2015) which stated that the application of IPM (Integrated Pest Control) in farming can provide higher rice production than without pest control.

Meanwhile, the dummy variable of tractor usage had a negative influence on technical inefficiency which means that land cultivation with tractors can reduce inefficiency. This was because the conditions of hybrid lowland rice farming in East Java were relatively outspread so that the use of tractors can save time and labor. 


\section{CONCLUSION}

In general, inbred lowland rice production was higher than hybrid lowland rice, with the inbred and hybrid lowland rice RTUP characteristics was majority of main farmers were men with the majority of having relatively low education, it was under junior high school and most farmers had done pest control efforts. In addition, most farmers had used tractors but most farmers did not attend counseling. Then, the majority of RTUP members were less or equal to four people. Meanwhile, the total cost of inbred lowland rice cultivation was higher than hybrid lowland rice but the production value produced by the hybrid lowland rice RTUP was higher than the inbred lowland RTUP. Thus, hybrid lowland rice cultivation was more profitable than inbred lowland rice cultivation.

The estimated results of the stochastic frontier production function of inbred lowland rice and hybrid lowland rice showed that three main input variables, which were harvested area and amount of fertilizer had a positive effect on production, while the seed variable negatively affected inbred lowland rice production and the labor variable was not significant. Meanwhile, the harvested area variable, the amount of fertilizer, seeds and labor, all have a positive and significant effect on hybrid lowland rice production. The average technical efficiency value of inbred lowland rice RTUP was 0.8117 which was in the high efficiency category. Meanwhile, the average value of technical efficiency of hybrid lowland rice farming was 0.7049 which was in the medium efficiency category.

The estimated results of the inefficiency function showed that gender, education, pest control, tractor usage, counseling, and the number of ART influenced the technical inefficiencies of inbred lowland rice RTUP, while education, pest control, and tractor usage variables influenced the technical inefficiency of hybrid lowland rice RTUP .

\section{RECOMMENDATION}

The government must provide fertilizer and seeds and ensure their distribution in the right amount, on time, at an affordable price by tightening the administrative discipline of fertilizer distributors. Next, the government should give more attention to the education of farmers who were still relatively low by providing socialization about the prospects of agriculture to the younger generation in order to make them interested to work in the agricultural sector. In addition, the quality of counselors also becomes very important to be improved so that they are more pro-active in providing counseling services to farmers. In addition, farmers should be more active in participating in counseling activities in their areas in order to find out the use of fertilizers and seeds to be in accordance with recommendations. Suggestions for further research, it can be carried out with similar research using other input variables, such as pesticides, organic fertilizers, and inorganic fertilizers.

\section{REFERENCES}

Badan Pusat Statistik. (2017). Hasil Survei Struktur Ongkos Usaha Tanaman Padi 2017. Badan Pusat Statistik RI.

Badan Pusat Statistik Jawa Timur. (2018). Luas Panen, Produktivitas, dan Produksi Komoditi Padi Sawah di Jawa Timur, 2002-2017. Badan Pusat Statistik. 
Direktorat Jenderal Tanaman Pangan. (2015). Rencana Strategis Direktorat Jenderal Tanaman Pangan Tahun 2015-2019. Kementerian Pertanian: Direktorat Jenderal Tanaman Pangan.

Direktorat Jenderal Tanaman Pangan. (2016). Pedoman Pelaksanaan Kegiatan 2017. Kementerian Pertanian: Dirjen Tanaman Pangan.

Irawan, B. (2004). Dinamika Produktivitas dan Kualitas Budidaya Padi Sawah. In Ekonomi Padi Dan Beras Indonesia (pp. 179-199). Badan Penelitian dan Pengembangan Pertanian.

Junaedi, M. (2016). Efisiensi dan Kesenjangan Teknologi Usahatani Padi Sawah di Indonesia. [Disertasi]. Bogor: Universitas Pertanian Bogor.

Kasturi, B. A. (2012). Analisis Faktor-faktor Yang Mempengaruhi Produksi Padi di Kabupaten Wajo. [Skripsi]. Makassar: Universitas Hasanuddin Makassar.

Peraturan Menteri Pertanian, Pub. L. No. 23/Permentan/SR.120/2/2007 tentang Pedoman Umum Peningkatan Produktivitas dan Produksi Padi, Jagung dan Kedelai Melalui Bantuan Benih (2007).

Peraturan Menteri Pertanian, Pub. L. No. 40/Permentan/OT.140/4/2007 tentang Rekomendasi Pemupukan N, P, dan K pada Padi Sawah Spesifik Lokasi (2007).

Kementerian Pertanian. (2018). Swasembada Pangan Suatu Keharusan. Kementerian Pertanian RI. https: / / www.pertanian.go.id/home/?show=news\&act=view\&id=2496

Kompas. (2017, July). Petani Sebaiknya Ganti Varietas Padi. https://kompas.id/baca/ekonomi/2017/07/03/petani-sebaiknya-gantivarietas-padi/

Krishnamurti, I., \& Biru, M. D. (2019). Prospek dan Tantangan Padi Hibrida di Indonesia. Center for Indonesia Policy Studies. www.cips-indonesia.org

Kusnadi, N., Tinaprilla, N., Susilowati, S. H., \& Purwoto, A. (2011). Analisis Efisiensi Usaha Tani Padi di Beberapa Sentra Produksi Padi di Indonesia. Jurnal Agro Ekonomi, $\quad$ Vol. $\quad 29 \quad$ No, $25-48$. http:/ / ejurnal.litbang.pertanian.go.id/index.php/jae/article/view/4041/337 0

Nwaru, J. C., Okoye, B. C., \& Ndukwu, P. C. (2011). Measurement and Determinants of Production Efficiency among Small-Holder Sweet Potato (Ipomoea Batatas) Farmers in Imo State, Nigeria. European Journal of Scientific Research, Vol. 59(3), 307-317. https://www.researchgate.net/publication/286721101_Measurement_and_de terminants_of_production_efficiency_among_smallholder_sweet_potato_ipomoea_batatas_farmers_in_Imo_State_Nigeria

Rivanda, D. R., Nahraeni, W., \& Yusdiarti, A. (2015). Analisi Efisiensi Teknis Usahatani Padi Sawah (Pendekatan Stochastic Frontier). Jurnal AgribiSains, Vol. 1 No., 1-13. https://ojs.unida.ac.id/AGB/article/view/140

Suharyanto, Mulyo, J. H., Darwanto, D. H., \& Widodo, S. (2015). Analisis Produksi dan Efisiensi Pengelolaan Tanaman Terpadu Padi Sawah di Provinsi Bali. 
Jurnal Penelitian Pertanian Tanaman Pangan, Vol. 34(2), 131-143. https: / / doi.org/10.21082/jpptp.v34n2.2015.p131-143

Tinaprilla, N. (2012). Efisiensi Usahatani Padi Antar Wilayah Sentra Produksi di Indonesia: Pendekatan Stochastic Metafrontier Production Function. [Disertasi]. Bogor: Universitas Pertanian Bogor. 